\title{
Effects of spacing and nitrogen levels on yield and yield contributing characters of maize
}

\author{
M. M. Rahman, S. K. Paul* and M. M. Rahman \\ Department of Agronomy, Bangladesh Agricultural University, Mymensingh 2202, Bangladesh \\ *E-mail: skpaull@gmail.com
}

\begin{abstract}
An experiment was conducted at the Agronomy Field Laboratory, Bangladesh Agricultural University, Mymensingh during November 2014 to April 2015 to investigate the effect of planting spacing and nitrogen levels on yield attributes and yield of maize cv. Khaibhutta. The experiment comprised three nitrogen levels viz. $50,100 \mathrm{and} 150 \mathrm{~kg}$ $\mathrm{N} \mathrm{ha}^{-1}$ and five plant spacings viz. $75 \mathrm{~cm} \times 25 \mathrm{~cm}, 75 \mathrm{~cm} \times 20 \mathrm{~cm}, 50 \mathrm{~cm} \times 25 \mathrm{~cm}, 50 \mathrm{~cm} \times 20 \mathrm{~cm}$ and $100 \mathrm{~cm} \times 20$ $\mathrm{cm}$. The experiment was laid out in a randomized complete block design with three replications. Results revealed that nitrogen levels and plant spacing had significant effect on yield attributes and yield of Khaibhutta. The highest number of cobs plant ${ }^{-1}$, grains row $^{-1}$, grain yield and stover yield were recorded with $150 \mathrm{~kg} \mathrm{~N}^{-1}$ followed by $100 \mathrm{~kg} \mathrm{~N}^{-}$ 1 and the lowest values were observed in $50 \mathrm{~kg} \mathrm{~N} \mathrm{ha}^{-1}$. The highest number of cobs plant ${ }^{-1}$, grain rows cob ${ }^{-1}, \mathrm{grains}^{-1}$ row $^{-1}$, grains $\mathrm{cob}^{-1}, 1000$-grain weight, grain yield and harvest index were recorded at $75 \mathrm{~cm} \times 25 \mathrm{~cm} \mathrm{spacing}$. In contrast, the closest spacing of $50 \mathrm{~cm} \times 20 \mathrm{~cm}$ produced the lowest values of grain rows $\mathrm{cob}^{-1}$, grains row ${ }^{-1}$, grains $\mathrm{cob}^{-1}, 1000$-grain weight and grain yield. In case of interaction, the highest grain yield and harvest index were obtained at $75 \mathrm{~cm} \times 25 \mathrm{~cm}$ spacing fertilized with $150 \mathrm{~kg} \mathrm{~N} \mathrm{ha}^{-1}$. The lowest values of the above parameters were recorded in the closest spacing $50 \mathrm{~cm} \times 20 \mathrm{~cm}$ with $50 \mathrm{~kg} \mathrm{~N} \mathrm{ha}^{-1}$. From this study it may be concluded that maize (cv. Khaibhutta) can be cultivated at the spacing of $75 \mathrm{~cm} \times 25 \mathrm{~cm}$ with $150 \mathrm{~kg} \mathrm{~N}^{-1}$ for appreciable grain yield.
\end{abstract}

Keywords: Planting spacing, Nitrogen, Maize, Yield attributes, Yield

\section{Introduction}

Maize (Zea mays L.) is one of the most important cereal crops of the world. In Bangladesh, the cultivation of maize has been gaining popularity in recent years because of its high productivity and diversified use (Tajul et al. 2013). In Bangladesh, it covers about 3.5 lac hectares of land producing 23 lac metric tons grains (Baral, 2016). Maize crop has been included as a major enterprise in the crop diversification and intensive cropping programmes (Zamir et al. 2011). As food, it can be consumed directly as green cob, roasted cob or popped grain. Its grains can be used for human consumption in various ways, such as, edible oil, corn meal, fried grain and flour. Green parts of the plant and grain are used as livestock and poultry feed. Sheaths of cobs are used to make paper of improved quality cigarettes. Stover, dry leaves, coverings of cobs and shelled cobs are used as good fuel (Ahmed, 1994). Maize is a major cereal crop for both livestock feed and human nutrition, worldwide. With its high content of carbohydrates, fats, proteins, some important vitamins and minerals, maize acquired a well-deserved reputation as a 'poor man nutricerea (Prasanna et al. 2001). So, maize can contribute in food and nutritional security program in Bangladesh because of its higher productivity and nutritional value. The average yield of maize in the country is not satisfactory. It is rather very low compared with leading maize growing countries of the world. The national average yield is only $6.45 \mathrm{t} \mathrm{ha}^{-1}$, whereas, the newly released varieties have the potential to produce more than $8 \mathrm{t} \mathrm{ha}^{-1}$ (AIS, 2015).

Plant population and fertilizer management usually affect on crop environment, which influence crop growth and yield. Less plant population and poor nutrient management practices are the major yield reducing factors in maize (Dawadi and Sah, 2012). Nitrogen fertilizer is universally accepted as a key component to high yield and optimum economic return as it plays very important part in crop productivity and its deficiency is one of the major yield limiting factors for cereal production. Balanced and optimum use of nitrogen plays a pivotal role in increasing the yield of maize (Sanjeev and Bangarwa, 1997). Nitrogen increases biomass production of a crop which largely depends on the function of leaf area development and consequential photosynthetic activity (Natr, 1992).

Plant spacing is another important factor which plays a significant role on growth, development and yield of maize. Optimum plant population provides scope to the plants for efficient utilization of solar radiation 
and nutrients. Sunlight can penetrate more easily and can reach the soil surface which may cause excessive evaporation of soil moisture. Closer spacing hampers intercultural operations and as such more competition arises among the plant for nutrients, air and light. As results, plant becomes shorter, weaker, thinner and consequently reduces yield of maize. Adjustment of proper plant spacing in the maize field is important to ensure maximum utilization of solar energy by the crop and reduce evaporation of soil moisture (FAO, 2012). So, optimum population should be maintained to exploit maximum natural resources, such as nutrients, sunlight, and soil moisture, to ensure satisfactory growth and yield. Narrow row spacing and higher plant density results to delay initiation of intraspecific competition (Duncan, 1984) while early crop growth is increased (Bullock et al. 1988). Thus the optimum nitrogen rate and appropriate plant spacing has to be ensured with a view to maximizing yield of maize. With the above view, an experiment was carried out to study the effect of planting spacing and nitrogen on yield performance of maize (cv. Khaibhutta).

\section{Materials and Methods}

The experiment was carried out at the Agronomy Field Laboratory, Department of Agronomy, Bangladesh Agricultural University, Mymensingh (24.75 N latitude and $90^{\circ} \mathrm{E}$ longitude) during November 2014 to April 2015 to study the effect of planting spacing and nitrogen on yield of maize. The experimental site belongs to the Old Brahmaputra Floodplain Agro-ecological Zone (AEZ-9) having non-calcareous dark gray floodplain soils of silty-loam texture (UNDP and FAO, 1988). The experiment was done in a randomized complete block design with three replications having three nitrogen levels viz. 50,100 , and $150 \mathrm{~kg} \mathrm{~N} \mathrm{ha}^{-1}$, and five planting spacings viz. $75 \mathrm{~cm} \times 25 \mathrm{~cm}, 75 \mathrm{~cm} \times 20 \mathrm{~cm}, 50 \mathrm{~cm} \times 25 \mathrm{~cm}, 50 \mathrm{~cm} \times 20 \mathrm{~cm}$ and 100 $\mathrm{cm} \times 20 \mathrm{~cm}$. The size of each unit plot was $4.5 \mathrm{~m} \times 4.0 \mathrm{~m}$. Nitrogen fertilizer was applied as per the experimental treatments and other fertilizers were applied in each unit plot according to the fertilizer recommendation guide (BARC, 2005). Full doses of triple super phosphate, muriate of potash, gypsum and Zinc sulphate @ $180 \mathrm{~kg}, 50 \mathrm{~kg}, 120 \mathrm{~kg}$ and $15 \mathrm{~kg} \mathrm{ha}^{-1}$ respectively and one-third of the urea were applied at the time of final land preparation. The remaining urea was applied in two equal splits on 40 and 75 days after sowing. Rows were oriented length wise in east-west direction. BARI developed maize cultivar Khaibhutta was used as test crop. The average life duration and yield in Rabi season is 125-130 days and 3.5-4.0 $\mathrm{t} \mathrm{ha}^{-1}$, respectively. Seeds were sown on 27 November 2015 as per experimental spacing apart by opening 3-4 cm deep furrows with tine. Two seeds were sown in each hill $^{-1}$. Weeding was done at 25, 50 and 70 DAS. Only one healthy seedling hill ${ }^{-1}$ was kept and the rest were thinned out at 14 DAS. The crop was irrigated two times at 40 and 80 DAS.

Five plants were randomly selected from each plot for collecting data on yield attributes and yield. At full maturity, the crop was harvested plot-wise on 25 April 2015. Cobs were dried in bright sunshine, shelled and the grains were cleaned properly. Grains and stalk were thoroughly dried plot by plot individually before their weights were recorded. Grains obtained from each unit plot were sun- dried to $14 \%$ moisture and weighed carefully and the plot yield was recorded in metric tons per hectare $\left(\mathrm{t} \mathrm{ha}^{-1}\right)$. Stalks obtained from each unit plot were dried in sun and final stalk yield per plot was recorded in $\mathrm{tha}^{-1}$. Harvest index $(\%)$ was calculated using the following formula:

Harvest index $=\frac{\text { Economic yield }(\text { grain yield })}{\text { Biological yield }(\text { grain yield }+ \text { stover yield })} \times 100$

The collected data were statistically analyzed using "Analysis of Variance" technique with the help of computer program, MSTAT. Mean differences among the treatments were adjudged by using the Duncun's Multiple Range Test (DMRT) (Gomez and Gomez, 1984). 


\section{Results and Discussion}

\section{Yield attributes}

The number of cobs plant ${ }^{-1}$, grains row $^{-1}$, grains $\mathrm{cob}^{-1}$ and thousand grain weight were significantly influenced by different nitrogen levels (Table 1). There was an increasing trend was observed in all the yield attributes with increasing nitrogen level. Similar trend of yield attributes were reported by Dawadi and Sah (2012). Maximum number of cobs plant ${ }^{-1}(1.44)$, grains row ${ }^{-1}(38.13)$, grains $\operatorname{cob}^{-1}(488.40)$ and thousand-grain weight $(117.56 \mathrm{~g})$ were obtained with $150 \mathrm{~kg} \mathrm{~N} \mathrm{ha}^{-1}$ followed by $100 \mathrm{~kg} \mathrm{~N}^{-1}$ and corresponding lowest values were recorded with $50 \mathrm{~kg} \mathrm{~N} \mathrm{ha}^{-1}$ (Table 1). This might be due to proper translocation of sugar and starch in the grain by nitrogen fertilization. A similar result was also reported by Shakarami and Rafiee (2009) and Pandey et al. (2002). The higher degree of infertility under lower (50 kg $\mathrm{N}$ ha $^{-1}$ ) application might be attributed to poor development of sinks and reduced translocation of photosynthates. Under nitrogen stress conditions there may be big chance to asynchronous flowering and seed infertility, thus reduction in the number of seeds $\mathrm{cob}^{-1}$. Gungula et al. (2007) reported that there will be more synchrony in flowering with higher nitrogen, thus reducing the rate of infertility during grain filling period. In agreement with the results of the present study, increased in thousand grain weight has been reported with increase in nitrogen levels (Niazuddin et al., 2002; Dawadi and Sah, 2012).

Table 1. Effect of nitrogen level on the yield attributes and yield of maize cv. Khaibhutta

\begin{tabular}{|c|c|c|c|c|c|c|c|c|}
\hline $\begin{array}{l}\text { Nitrogen } \\
\left(\mathrm{kg} \mathrm{ha}^{-1}\right)\end{array}$ & $\begin{array}{l}\text { Cobs } \\
\text { plant }^{-1} \\
\text { (no.) }\end{array}$ & $\begin{array}{c}\text { Grain rows } \\
\text { cob }^{-1} \\
\text { (no.) }\end{array}$ & $\begin{array}{l}\text { Grains } \\
\text { row }^{-1} \\
\text { (no.) }\end{array}$ & $\begin{array}{l}\text { Grains } \\
\text { cob }^{-1} \\
\text { (no.) }\end{array}$ & $\begin{array}{c}\text { 1000- grain } \\
\text { weight } \\
\text { (g) }\end{array}$ & $\begin{array}{c}\text { Grain } \\
\text { yield } \\
\left(\mathrm{t} \mathrm{ha}^{-1}\right)\end{array}$ & $\begin{array}{l}\text { Stover } \\
\text { yield } \\
\left(\mathrm{t} \mathrm{ha}^{-1}\right)\end{array}$ & $\begin{array}{c}\text { Harvest } \\
\text { index } \\
(\%) \\
\end{array}$ \\
\hline 50 & $1.24 \mathrm{c}$ & 12.27 & $33.60 \mathrm{~b}$ & $413.87 \mathrm{~b}$ & 111.42 & $3.98 \mathrm{c}$ & $6.06 \mathrm{c}$ & $39.14 b$ \\
\hline 100 & $1.32 b$ & 12.80 & $37.73 a$ & 486Z.07a & 115.52 & $5.02 b$ & $6.67 \mathrm{~b}$ & $42.97 a$ \\
\hline 150 & $1.44 a$ & 12.80 & $38.13 a$ & $488.40 a$ & 117.56 & $5.17 a$ & $7.24 a$ & $41.66 a$ \\
\hline CV (\%) & 2.12 & 4.54 & 4.58 & 4.72 & 4.62 & 1.11 & 6.89 & 3.00 \\
\hline $\begin{array}{c}\text { Level of } \\
\text { significance }\end{array}$ & ** & NS & ** & ** & ** & ** & ** & ** \\
\hline
\end{tabular}

Figures in a column having the same letter(s) or without letter do not differ significantly whereas figures with dissimilar letters differ significantly as per DMRT.

** indicates significance at 0.01 level probability NS- indicates non-significant

Planting spacing of $75 \mathrm{~cm} \times 25 \mathrm{~cm}$ produced the highest number of cobs plant ${ }^{-1}(1.37)$, grain rows $\operatorname{cob}^{-1}$ (13.11), grains $\mathrm{cob}^{-1}(517.22)$ and thousand-grain weight (128.76 g) while the lowest values of all those attributes were recorded at spacing of $50 \mathrm{~cm} \times 20 \mathrm{~cm}$ (Table 2). The lowest values for yield attributes in closer spacing were due to high competition for the resources such as sun light, moisture, nutrient and air. Similar trend was reported elsewhere (Hashemi et al. 2005; Dawadi and Sah 2012). They reported the negative relationship between yields attributes with increasing plant density. In case of closest spacing of $50 \mathrm{~cm} \times 20 \mathrm{~cm}$ with high plant densities decreased the yield attributes due to the absence of the usual sink for the assimilate supply and limiting optimum conservation of light energy. The highest number of cob plant ${ }^{-1}(1.67)$, grain rows $\mathrm{cob}^{-1}(14.00)$ and grains $\mathrm{cob}^{-1}(564.67)$ were obtained from 150 $\mathrm{kg} \mathrm{N}$ ha with $75 \mathrm{~cm} \times 25 \mathrm{~cm}$ spacing while the lowest values of all those attributes were found in $50 \mathrm{~kg} \mathrm{~N}$ ha $^{-1}$ with $50 \mathrm{~cm} \times 20 \mathrm{~cm}$ spacing (Table 3 ). 
Table 2. Effect of plant spacing on the yield attributes and yield of maize cv. Khaibhutta

\begin{tabular}{|c|c|c|c|c|c|c|c|c|}
\hline $\begin{array}{l}\text { Spacing } \\
(\mathrm{cm} \times \mathrm{cm})\end{array}$ & $\begin{array}{l}\text { Cobs } \\
\text { plant }^{-1} \\
\text { (no.) }\end{array}$ & $\begin{array}{c}\text { Grains } \\
\text { rows } \\
\mathrm{cob}^{-1} \text { (no.) }\end{array}$ & $\begin{array}{l}\text { Grains } \\
\text { row }^{-1} \\
\text { (no.) } \\
\end{array}$ & $\begin{array}{l}\text { Grains } \\
\text { cob }^{-1} \\
\text { (no.) }\end{array}$ & $\begin{array}{c}1000- \\
\text { grain } \\
\text { weight }(\mathrm{g})\end{array}$ & $\begin{array}{c}\text { Grain } \\
\text { yield } \\
\left(\mathrm{t} \mathrm{ha}^{-1}\right)\end{array}$ & $\begin{array}{c}\text { Stover } \\
\text { yield } \\
\left(\mathrm{t} \mathrm{ha}^{-1}\right)\end{array}$ & $\begin{array}{c}\text { Harvest } \\
\text { index }(\%)\end{array}$ \\
\hline $75 \times 25$ & $1.37 a$ & $13.11 a$ & $39.44 a$ & $517.22 a$ & 128.76a & $5.01 a$ & $6.77 b$ & $42.52 a$ \\
\hline $75 \times 20$ & $1.34 a b$ & $12.78 a$ & $37.67 b$ & $481.56 b$ & $110.36 b$ & $4.87 b$ & $7.46 a$ & $39.49 b$ \\
\hline $50 \times 25$ & $1.33 b$ & $12.56 a$ & $36.44 b$ & $458.00 \mathrm{c}$ & $104.80 c$ & $4.69 c$ & $6.55 \mathrm{bc}$ & $41.73 a$ \\
\hline $50 \times 20$ & $1.26 a$ & $11.56 b$ & $31.11 \mathrm{c}$ & $361.22 d$ & $101.73 c$ & $4.45 \mathrm{e}$ & $6.37 \mathrm{bc}$ & $41.13 a$ \\
\hline $100 \times 20$ & $1.36 a$ & $13.11 \mathrm{a}$ & $37.78 b$ & $495.89 b$ & $128.51 a$ & $4.59 \mathrm{~d}$ & $6.13 c$ & $42.82 b$ \\
\hline CV (\%) & 2.12 & 4.54 & 4.58 & 4.72 & 4.62 & 1.11 & 6.89 & 3.00 \\
\hline $\begin{array}{c}\text { Level of } \\
\text { significance }\end{array}$ & ** & ** & ** & ** & ** & ** & $* *$ & ** \\
\hline
\end{tabular}

Figures in a column having the same letter(s) or without letter do not differ significantly whereas figures with dissimilar letters differ significantly as per DMRT.

${ }^{* *}$ indicates significance at 0.01 level probability

Table 3. Interaction effect of nitrogen level and plant spacing on the yield attributes and yield of maize cv. Khaibhutta

\begin{tabular}{|c|c|c|c|c|c|c|c|c|}
\hline $\begin{array}{c}\text { Interaction } \\
\text { (Nitrogen } \times \\
\text { Spacing) }\end{array}$ & $\begin{array}{l}\text { Cobs } \\
\text { plant }^{-1} \\
\text { (no.) }\end{array}$ & $\begin{array}{c}\text { Grain rows } \\
\mathrm{cob}^{-1} \\
\text { (no.) }\end{array}$ & $\begin{array}{l}\text { Grains } \\
\text { row }^{-1} \\
\text { (no.) }\end{array}$ & $\begin{array}{l}\text { Grains } \\
\text { cob }^{-1} \\
\text { (no.) }\end{array}$ & $\begin{array}{l}\text { 1000-grain } \\
\text { weight(g) }\end{array}$ & $\begin{array}{c}\text { Grain } \\
\text { yield } \\
\left(\mathrm{t} \mathrm{ha}^{-1}\right)\end{array}$ & $\begin{array}{c}\text { Stover } \\
\text { yield } \\
\left(\mathrm{t} \mathrm{ha}^{-1}\right)\end{array}$ & $\begin{array}{c}\text { Harvest } \\
\text { index } \\
(\%)\end{array}$ \\
\hline$N_{1} \times S_{1}$ & 1.27 ef & $12.33 \mathrm{bc}$ & $35.33 b c$ & 435.00ef & $142.55 a$ & $4.33 \mathrm{j}$ & $5.46 \mathrm{def}$ & $44.23 b c$ \\
\hline $\mathrm{N}_{1} \times \mathrm{S}_{2}$ & $1.23 \mathrm{fg}$ & $12.67 b$ & $33.33 \mathrm{~cd}$ & $422.00 f$ & $116.47 \mathrm{~cd}$ & $4.20 \mathrm{k}$ & 5.26def & $44.39 b c$ \\
\hline$N_{1} \times S_{3}$ & $1.19 \mathrm{~g}$ & $12.33 b c$ & $31.00 \mathrm{de}$ & $382.00 \mathrm{~g}$ & 103.00ef & 4.021 & $5.73 \mathrm{cdef}$ & $43.24 \mathrm{bcd}$ \\
\hline $\mathrm{N}_{1} \times \mathrm{S}_{4}$ & $1.18 \mathrm{~g}$ & $11.00 d$ & $28.33 e$ & $311.67 \mathrm{~h}$ & $98.41 f$ & $3.74 \mathrm{~m}$ & $4.91 \mathrm{ef}$ & $43.24 \mathrm{bcd}$ \\
\hline $\mathrm{N}_{1} \times \mathrm{S}_{5}$ & $1.31 \mathrm{de}$ & 13.00ab & $40.00 a$ & $518.67 \mathrm{bc}$ & $127.35 b$ & $3.62 n$ & $4.80 f$ & $42.93 \mathrm{~cd}$ \\
\hline $\mathrm{N}_{2} \times \mathrm{S}_{1}$ & $1.39 b c$ & $14.00 \mathrm{a}$ & $39.00 \mathrm{a}$ & $546.00 \mathrm{ab}$ & $116.20 \mathrm{~cd}$ & $5.33 c$ & $6.65 a$ & $44.49 b c$ \\
\hline $\mathrm{N}_{2} \times \mathrm{S}_{2}$ & $1.37 \mathrm{~cd}$ & $12.67 b$ & $39.00 \mathrm{a}$ & $494.00 \mathrm{~cd}$ & 111.21cde & $5.05 e$ & $6.20 b$ & $44.89 b c$ \\
\hline $\mathrm{N}_{2} \times \mathrm{S}_{3}$ & $1.25 f$ & $12.67 b$ & $39.00 a$ & $494.00 \mathrm{~cd}$ & 108.25def & $4.99 e$ & $6.19 b c$ & $44.63 b c$ \\
\hline $\mathrm{N}_{2} \times \mathrm{S}_{4}$ & $1.25 f$ & $12.33 b c$ & $35.67 b c$ & 439.67ef & 102.37 ef & $4.71 \mathrm{~g}$ & $5.76 \mathrm{cdef}$ & $44.96 \mathrm{bc}$ \\
\hline $\mathrm{N}_{2} \times \mathrm{S}_{5}$ & $1.36 \mathrm{~cd}$ & $12.33 \mathrm{bc}$ & 38.00ab & 468.33de & $139.55 a$ & $4.43 i$ & $5.90 \mathrm{bcd}$ & 42.89de \\
\hline $\mathrm{N}_{3} \times \mathrm{S}_{1}$ & $1.43 b$ & $13.00 \mathrm{ab}$ & $39.00 a$ & $506.67 \mathrm{bcd}$ & $126.78 b$ & $5.79 a$ & $6.80 a$ & $45.62 a$ \\
\hline $\mathrm{N}_{3} \times \mathrm{S}_{2}$ & $1.39 \mathrm{bc}$ & 13.00ab & $40.67 a$ & $528.67 a b c$ & 103.39ef & $5.62 b$ & $6.70 a$ & $45.52 b$ \\
\hline $\mathrm{N}_{3} \times \mathrm{S}_{3}$ & $1.36 \mathrm{~cd}$ & $12.67 b$ & $39.33 a$ & $498.00 \mathrm{~cd}$ & 103.14ef & $5.53 d$ & $6.62 a$ & $45.32 b$ \\
\hline $\mathrm{N}_{3} \times \mathrm{S}_{4}$ & $1.35 \mathrm{~cd}$ & $11.33 \mathrm{~cd}$ & $29.33 e$ & $332.33 \mathrm{~h}$ & $104.41 \mathrm{ef}$ & $4.88 f$ & $5.89 \mathrm{bcd}$ & $44.18 b c$ \\
\hline $\mathrm{N}_{3} \times \mathrm{S}_{5}$ & $1.67 a$ & $14.00 \mathrm{a}$ & $40.33 a$ & $564.67 a$ & $119.39 \mathrm{bc}$ & $4.59 \mathrm{~h}$ & 5.80 bcde & $42.49 \mathrm{e}$ \\
\hline CV (\%) & 2.12 & 4.54 & 4.58 & 4.72 & 4.62 & 1.11 & 6.9 & 3.00 \\
\hline $\begin{array}{c}\text { Level of } \\
\text { significance }\end{array}$ & $* *$ & $* *$ & $* *$ & $* *$ & $* *$ & $* *$ & $* *$ & ** \\
\hline
\end{tabular}

Figures in a column having the same letter(s) or without letter do not differ significantly whereas figures with dissimilar letters differ significantly as per DMRT.

** indicates significance at 0.01 level probability

$\mathrm{N}_{1}: 50 \mathrm{~kg} \mathrm{~N} \mathrm{ha}^{-1}, \mathrm{~N}_{2}: 100 \mathrm{~kg} \mathrm{~N} \mathrm{ha}^{-1}, \mathrm{~N}_{3}: 150 \mathrm{~kg} \mathrm{~N} \mathrm{ha}^{-1}$

$\mathrm{S}_{1}: 75 \mathrm{~cm} \times 25 \mathrm{~cm}, \mathrm{~S}_{2}: 75 \mathrm{~cm} \times 20 \mathrm{~cm}, \mathrm{~S}_{3}: 50 \mathrm{~cm} \times 25 \mathrm{~cm}, \mathrm{~S}_{4}: 50 \mathrm{~cm} \times 20 \mathrm{~cm}, \mathrm{~S}_{5}: 100 \mathrm{~cm} \times 20 \mathrm{~cm}$ 


\section{Grain yield, stover yield and harvest index}

Grain yield, stover yield and harvest index were significantly influenced by nitrogen level (Table 1). The highest grain yield $\left(5.17 \mathrm{t} \mathrm{ha}^{-1}\right)$ was obtained with $150 \mathrm{~kg} \mathrm{~N} \mathrm{ha}^{-1}$ and the lowest yield $\left(3.98 \mathrm{t} \mathrm{ha}^{-1}\right)$ was achieved with $50 \mathrm{~kg} \mathrm{~N} \mathrm{ha}^{-1}$ (Table 1). The increasing nitrogen levels increased the number of cobs plant ${ }^{-1}$, grains cob- ${ }^{1}$ and thousand-grain weight which resulted in the highest grain yield. Application of $150 \mathrm{~kg} \mathrm{~N}$ $\mathrm{ha}^{-1}$ produced maximum number of grains $\mathrm{row}^{-1}$, grains $\mathrm{cob}^{-1}$ and 1000-grain weight,which resulted in the highest grain yield. Similar trend was obtained in stover yield due to nitrogen fertilization. The highest stover yield $\left(7.24 \mathrm{t} \mathrm{ha}^{-1}\right)$ was obtained when $150 \mathrm{~kg} \mathrm{~N} \mathrm{ha}^{-1}$ was applied which was significantly higher than those of the plots received $100 \mathrm{~kg} \mathrm{~N} \mathrm{ha}^{-1}\left(6.67 \mathrm{t} \mathrm{ha}^{-1}\right)$ and $50 \mathrm{~kg} \mathrm{~N} \mathrm{ha}^{-1}\left(6.06 \mathrm{t} \mathrm{ha}^{-1}\right)$. Grain and stover yield increased with increase in nitrogen levels was reported elsewhere (Ullah et al., 2007; Dahmardeh, 2011; Dawadi and Sah, 2012). Harvest index increased due to application of higher dose of nitrogen from $50 \mathrm{~kg}$ to $100 \mathrm{~kg} \mathrm{ha}^{-1}$ and thereafter declined. The highest harvest index $(42.97 \%)$ was obtained when fertilized with $100 \mathrm{~kg} \mathrm{~N}^{-1}$ which was significantly identical with $150 \mathrm{~kg} \mathrm{~N}^{-1}$ and the lowest one $(39.14 \%)$ was achieved with $50 \mathrm{~kg} \mathrm{~N} \mathrm{ha}^{-1}$. Sahar et al. (2005) stated that grain and stalk yield were significantly influenced by the increased rate of nitrogen thus increased the harvest index.

Grain yield, stover yield and harvest index were significantly influenced by planting spacing (Table 2). The grain yield at planting spacing of $75 \mathrm{~cm} \times 25 \mathrm{~cm}$ was the highest $\left(5.01 \mathrm{t} \mathrm{ha}^{-1}\right)$ and the lowest one $(4.45 \mathrm{t}$ $\mathrm{ha}^{-1}$ ) was recorded at $50 \mathrm{~cm} \times 20 \mathrm{~cm}$ spacing (Table 2). Due to closer spacing grain yield gradually decreased. Under closer planting spacing, the rate of yield reduction was in response to decreasing solar radiation, nutrient, moisture and air. This result is in agreement with that of Ramulu et al. (2006). On the contrary, Dawadi and Sah (2012) found the positive relationship between grain yield and plant density due to the high number of cobs harvested from high number of plants unit ${ }^{-1}$ area. The maximum stover yield $\left(7.46 \mathrm{tha}^{-1}\right)$ was recorded at the spacing of $75 \mathrm{~cm} \times 20 \mathrm{~cm}$ followed by $75 \mathrm{~cm} \times 25 \mathrm{~cm}\left(6.77 \mathrm{t} \mathrm{ha}^{-1}\right)$ which was statistically identical to the spacing of $50 \mathrm{~cm} \times 25 \mathrm{~cm}$ and $50 \mathrm{~cm} \times 20 \mathrm{~cm}$ the lowest one $(6.13 \mathrm{t}$ $\mathrm{ha}^{-1}$ ) was recorded at $100 \mathrm{~cm} \times 20 \mathrm{~cm}$ spacing. The spacing of $100 \mathrm{~cm} \times 20 \mathrm{~cm}$ produced the highest index (42.82\%) followed by $75 \mathrm{~cm} \times 25 \mathrm{~cm}(42.52 \%)$ and the lowest harvest index $(39.49 \%)$ was recorded at $75 \mathrm{~cm} \times 20 \mathrm{~cm}$ spacing. Grain yield, stover yield and harvest index were significantly influenced by the interaction between nitrogen rate and planting spacing. The highest grain yield $(5.79 \mathrm{t}$ $\left.\mathrm{ha}^{-1}\right)$, stover yield $\left(8.40 \mathrm{t} \mathrm{ha}^{-1}\right)$ and harvest index (45.62\%) were found with $150 \mathrm{~kg} \mathrm{~N} \mathrm{ha}^{-1}$ at $75 \mathrm{~cm} \times 20$ $\mathrm{cm}$ spacing (Table 3$)$. The lowest grain yield $\left(3.62 \mathrm{tha}^{-1}\right)$, and stover yield $\left(4.80 \mathrm{tha}^{-1}\right)$ were obtained from $50 \mathrm{~kg} \mathrm{~N} \mathrm{ha}^{-1}$ with $50 \mathrm{~cm} \times 20 \mathrm{~cm}$ spacing.

\section{Conclusion}

Based on the present study, it may be concluded that planting at $75 \mathrm{~cm} \times 25 \mathrm{~cm}$ spacing and application of $150 \mathrm{~kg} \mathrm{~N} \mathrm{ha}^{-1}$ could be considered for obtaining higher yield of maize cv. Khaibhutta.

\section{References}

Ahmed, F. 1994. Maize Production Technology (in Bengali). International Fertilizer Development Center (IFDC)-Consultant of Ministry of Agriculture, Bangladesh.

AIS (Agriculture Information Service). 2015. Area, production and yield of different crops. Agriculture Information Service. Khamarbari, Dhaka. pp. 14.

BARC (Bangladesh Agricultural Research Council). 2005. Fertilizer Recommended Guide, Bangladesh Agricultural Research Council (BARC), Farm gate, Dhaka, Bangladesh. pp. 12.

Baral, B. 2016. Agricultural Market information system (AMIS) in Bangladesh. Asia and pacific commission on agricultural statistics. Twenty-sixth Session on Asia and Pacific Commission on Agriculture Statistics, (15-19 February), Thimphu, Bhutan.

Bullock, D., Nielsen, R. and Nyquist, J. W. 1988. A growth analysis comparison of corn grown in conventional and equidistant plant spacing. Crop Sci. 28:254-259.

Dahmardeh, M. 2011. Effect of plant density and nitrogen rate on PAR absorption and maize yield. American Journalof Plant Physiology, 6: 44-49.

Dawadi, D. R. and Sah, S. K. 2012. Growth and yield of hybrid maize (Zea mays L.) in relation to planting density and nitrogen levels during winter season in Nepal. Tropical Agricultural Research, 23 (3): 218-227. 
Duncan, W. 1984. A theory to explain the relationship between corn population and grain yield. Crop Sci. 24:1141-1145.

FAO (Food and Agriculture Organization). 2012. Production report of agricultural crop 2010. (Online available at http://faostat.fao.org/site/339/default.aspx).

Gomez, K.A. and Gomez, A.A. 1984. Statistical Procedure for Agricultural Research -International Rice Research Institute Book, A Wiley Interscience, John Wiley and Sons Inc., New York, USA. 680p.

Gungula, D. T., Togun, A. O. and Kling, J. G. 2007. The effect of nitrogen rates on phenology and yield components of early maturing maize cultivars. Glob. J. Pur. App. Sci. 13 (3): 319-324.

Hashemi, A.M., Herbert, S. J. and Putnam, D. H. 2005. Yield response of corn to crowding stress. Agron. J. 97:839-846.

Natr, L. 1992. Mineral nutrients an iniquitous stress factor for photosynthesis. Photosynthetica, 27: 271-295.

Niazuddin, M., Talukder, M.S.U., Shirazi, S.M., Adham, A.K.M. and Hye, M.A. 2002. Response of maize to irrigation and nitrogenous fertilizer. Bangladesh J. Agric. Sci. 29 (2): 283-289

Pandey, A.K., Mani,V.P., Prakash, V., Singh, R.D. and Gupta, H.S. (2002). Effect of varieties and plant densities on yield, yield attributes and economics of baby corn (Zea mays). Indian J. Agron. 47(2): 221-226.

Prasanna, B.M., Vasal, S.K., Kassahun B. and Singh, N.N. 2001. Quality protein maize. Current Sci. 81 (10): 1308-1319.

Ramulu, V., Suresh, K. and Balaguravaiah, K. 2006. Effect of irrigation schedules and nitrogen levels on the grain yield of maize in alfisols of NSP left canal command area. Ann. Agril. Res .(New Series) 27(4): 389-391.

Sahar, A.K., Zorer, R., Celebi, A. E. and Celen, S. 2005. The effect of different forms and doses of N fertilizer on the silage yield of maize (Zea mays L.). 5th Field Crops Congress in Turkey, 5-9 Semptember, 2005, 1001-1004, Antalya.

Sanjeev K. and Bangarwa, A.S. 1997. Yield and yield components of winter maize (Zea mays L.) as influenced by plant density and nitrogen levels. Agricultural Science Digest, 17: 181-184.

Shakarami, G. and Rafiee, M. 2009. Response of Corn (Zea mays L.) to planting pattern and density in Iran. American-Eurasian J. Agric. \& Environ. Sci. 5 (1): 69-73.

Tajul, M.I., Alam, M.M. Hossain, S.M.M. Naher, K. Rafii, M.Y. and Latif M.A. 2013. Influence of plant population and nitrogenfertilizer at various levels on growth and growth efficiency of maize. The Scientific World J. 2013: 1-9 (http://dx.doi.org/10.1155/2013/193018).

Ullah, A.M., Bhatti, A., Gurmani, Z.A. and Imran, M. 2007. Studies on planting patterns of maize facilitating legumes intercropping. J. Agric. Res. 45(2): 1-5.

UNDP and FAO 1988. Land Resources Appraisal of Bangladesh for Agricultural Development. Report 2. Agroecological Regions of Bangladesh. United Nations Development Programme and Food and Agriculture Organization. pp. 212-221.

Zamir, M.S.I., Ahmad, A.H., Javeed, M.R. and Latif, T. 2011. Growth and yield behaviour of two maize hybrids (Zea mays L.) towards different plant spacing. Cercetări Agronomice în Moldova. 14(2): 33-40. 